\title{
IoT 技術の最新動向
}

\author{
Latest Trends in loT Technologies
}

\section{鈴木一哉 Kazuya Suzuki ${ }^{\dagger}$, 森本昌治 Masaharu Morimoto ${ }^{\dagger}$, 岩井孝法 Takanori Iwai ${ }^{\dagger}$}

近年 全ての ‘もの’をインターネットにつなぐというloT（Internet of Things）という考え方に基づき, 実社会の課題解決を目指した技術の研究・開発が盛んに行われている. IoTでは，気温や監視カメラの映 像など実社会に関わる情報をインターネットに接続された ‘もの’により収集し，クラウド上にて動作するデータ分析技術を用 いて分析・判断し，更にはインターネットを通じて実社会にフィードバックする. loT が大きく注目されている背景には，モバ イル網に代表されるネットワーク及びクラウドの成熟と各種データ分析技術の発展が挙げられる. しかし, loTを活用した様々 なユースケースの実現を考えたとき，既存のクラウドネットワークには椂々な課題が存在する. 本論文では, IoTを活用する上 でのクラウドネットワークの課題を挙げ, 課題解決のための技術を解説する.

loT, エッジコンピューティング, LPWA, IoT プラットホーム

\section{はじめに}

近年全ての囚もの’をインターネットにつなぐと いう IoT (Internet of Things) という考光方に基 づき, 実社会の課題解決を目指した技術の研究・開 発が盛んに行われている。IOTでは，気温や監視力 メラの映像など実社会に関わる情報をインターネッ トに接続された囚もの’ (以降「IoT 端末」と呼ぶ) により収集し，クラウド上にて動作するデータ分析 技術を用いて分析・判断し，更にはインターネット を通じて実社会にフィードバックする。これらによ り, ‘もの’のデータ化やそれに基づく自動化が進 展し, 新たな付加価值を生み出すのが IoT のコン セプトである ${ }^{(1)}$ 。例えば，促成栽培において，作 物生育状況と測定した温度や日照などの関係を分析 し，八ウス内の温度を適切に保つょう暖房・空調設 備などを制御することで, 作物の収穫量を高める. 本論文では, インターネットに接続し, このコンセ プトを実現する・もの’をIoT 端末と呼ぶ.

IoT が大きく注目されている背景には, 様々な要 因があるが，モバイル網に代表されるネットワーク 及びクラウドの成熟とディープラーニングに代表さ れるデー夕分析技術の発展が大きいと考えられる。 誰もがクラウド上のコンピューティング資源を必要

日本電気株式会社，川崎市

NEC Corporation, Kawasaki-shi, 211-8666 Japan
なときに借りることができ，その上で動作させる デー夕分析ソフトウェアも数多くオープンソースと して公開されている。ある程度の知識さえあれば, 誰もがネットワークに接続された端末からのデー夕 をクラウド上に集め, クラウド上で分析するとい ったことが，現在容易に実現できる。

しかし，IoTを活用した様々なユースケースを考 えると, 既存のクラウドネットワークには, 以下に 示す様々な課題が存在する（図 1 ).

・膨大な数の IoT 端末の収容 : ネットワークに つながる IoT 端末の数は，年率 $12 \%$ から $15 \%$ で増加を続け, 2020 年には 300 億台になると 予想されている ${ }^{(2)}$. 膨大な数の IoT 端末を, 安価にネットワークに接続する技術が求められ ている.

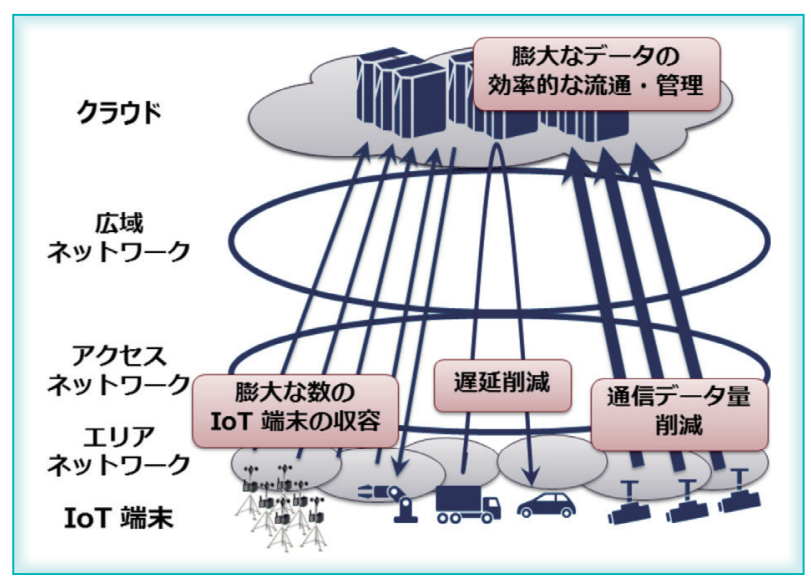

図 1 IOT 活用上の課題 
・遅延削減：自動車の衝突回避といったユース ケースでは, 数十 $\mathrm{ms}$ 程度の遅延でお互いの位 置情報を交換する必要がある。しかし，クラウ ドを経由した場合，この制約を満たすことは難 しいため, 低遅延を実現する必要がある.

・通信デー夕量の削減 : 高精細な監視カメラの映 像をクラウド上で分析するケースでは, ネット ワーク帯域の圧迫を防ぐために, 通信デー夕量 を削減する必要がある。また，後に述べる狭帯 域無線技術は, 通信デー夕量を削減すること で，適用範囲を広げられる。

・膨大なデー夕の効率的な流通・管理 : クラウド 上には膨大な量のデータが集まり，またそれら を活用する様々なアプリケーションが動作す る、膨大な情報を, 適切に管理し, 必要とする アプリケーションに送るためのプラットホーム が必要となる。

本稿では, 先に挙げた IoT を活用する上での課 題を解決するための技術を解説する. 2.では, 多 数 IoT 端末からの情報を安価に収集するための無 線技術として, 近年注目されているLPWA を解説 する. 3.にて, 低遅延・通信量削減のために活用 に向けた議論が進められているエッジコンピュー ティングを紹介する，最後に，IoT端末からの情報 を集め, 必要とするアプリケーションへと流通させ るためのプラットフォーム技術を，4. で説明する。

\section{多数の IoT 端末からの情報を安価に 収集する LPWA 技術}

多数の IoT 端末からセンサデー夕など少量のデー 夕を送るために，より省電力かつ安価な無線技術が 求められている。また, IoT 端末は屋内だけではな

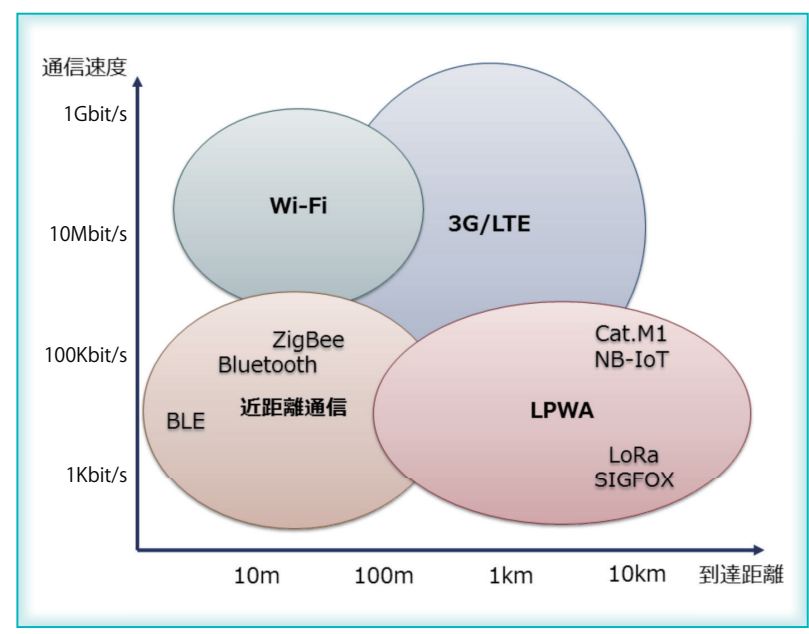

図 2 LPWA 方式の位置付け
く, 屋外でも利用されるため, この無線技術は省電 力であっても長距離到達可能である必要がある。こ のような背景の下，近年 LPWA（Low-Power Wide-Area）と呼ばれる無線技術が開発され, 活 用が始まっている. LPWA の位置付けを, 図 2 に 示す. LPWA は省電力・長距離到達可能である代 わりに, 通信速度は 100bit/s から 800kbit/s 程度 となっている。

主な LPWA 方式として, 免許不要で利用可能な 周波数帯（日本においては 920MHz 帯）を使用す る SIGFOX, LoRa と, 免許が必要な周波数帯 (LTE の周波数帯) を使用する eMTC や NB-IoT がある (表 1)。これらは, MIMO 非対応, 半二重, デー 夕処理簡素化などにより, チップの構造を簡素化 し，チップコストを低減している. SIGFOX, LoRaは，少ない基地局で広いエリアをカバーする ために, 雑音の影響を軽減し, 長距離到達性を上げ る技術を採用している，本稿では，2.1にて LoRa 及びSIGFOXにおける雑音軽減・長距離伝送のた めの技術について説明する。 また，LTEを IoT 向 けに拡張した仕様である eMTC や NB-IoT に関し ては, 従来の LTE での制御の改良による省電力化 技術を 2.2 で説明する。

\subsection{LoRa, SIGFOX}

LoRa とはSEMTECH 社が開発した変調方式 (3), (4) で, チャープ拡散 ${ }^{(5)}$ と呼ばれるスペクトル拡散方 式に独自拡張を加えたものである。チャープ拡散で は, 一次変調された信号の周波数を時間の経過とと もに変化させて送信する（図 3 )。受信側の復号処 理では, 周波数を変えながら時間方向に拡散された 信号を集め，元の信号へと戻す。この処理により， 帯域内の一部の周波数で発生する干渉, 雑音の影響

表 1 主な LPWA 方式

\begin{tabular}{|c|c|c|c|c|c|}
\hline \multirow{2}{*}{\multicolumn{2}{|c|}{ 無線方式 }} & \multirow[b]{2}{*}{ LoRa } & \multirow[b]{2}{*}{ SIGFOX } & \multicolumn{2}{|c|}{ LTE } \\
\hline & & & & $\begin{array}{l}\text { Cat.M1 } \\
\text { (eMTC) }\end{array}$ & $\begin{array}{l}\text { Cat.NB1 } \\
\text { (NB-loT) }\end{array}$ \\
\hline \multicolumn{2}{|c|}{$\begin{array}{l}\text { 日本での } \\
\text { 周波数帯 }\end{array}$} & \multicolumn{2}{|c|}{$\begin{array}{l}\text { 920MHz 帯 } \\
\text { (免許不要) }\end{array}$} & \multicolumn{2}{|c|}{$\begin{array}{c}\text { 800/900MHz 帯 } \\
\text { (免許必要) }\end{array}$} \\
\hline \multicolumn{2}{|c|}{ 運用帯域幅 } & $125 \mathrm{kHz}$ & $100 \mathrm{~Hz}$ & $1.08 \mathrm{MHz}$ & $180 \mathrm{kHz}$ \\
\hline \multirow{2}{*}{$\begin{array}{l}\text { 伝送 } \\
\text { 速度 }\end{array}$} & 上り & \multirow{2}{*}{$\sim 5 \mathrm{kbit} / \mathrm{s}$} & \multirow{2}{*}{ 100bit/s } & \multirow{2}{*}{ 800kbit/s } & $\sim 22 \mathrm{kbit} / \mathrm{s}$ \\
\hline & 下り & & & & $\sim 62 \mathrm{kbit} / \mathrm{s}$ \\
\hline \multicolumn{2}{|c|}{ 運用形態 } & $\begin{array}{c}\text { 公衆 } \\
\text { サービス } \\
\text { 自営網 }\end{array}$ & & \multicolumn{2}{|c|}{ 公衆サービス } \\
\hline
\end{tabular}




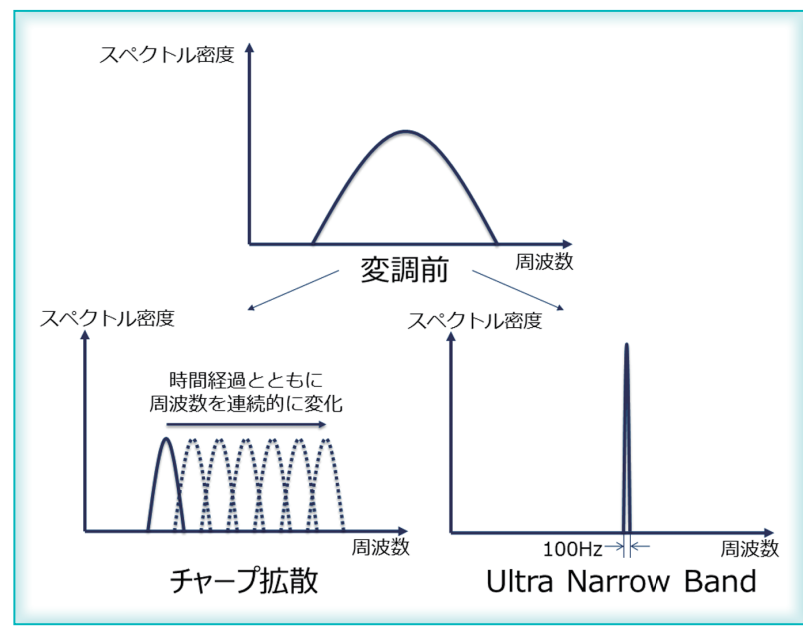

図 3 チャープ拡散とUItra Narrow Band

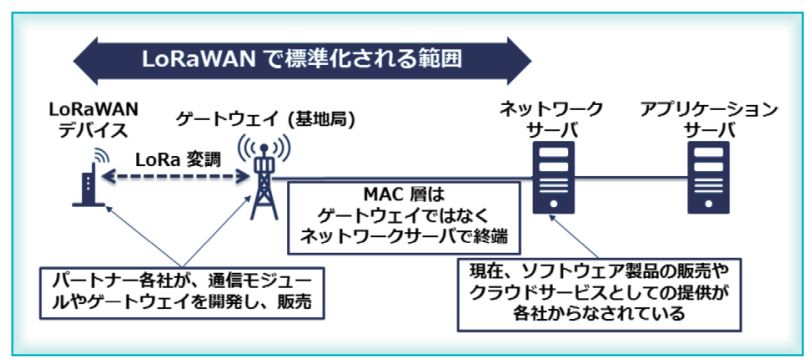

図 4 LoRaWAN アーキテクチャとエコシステム

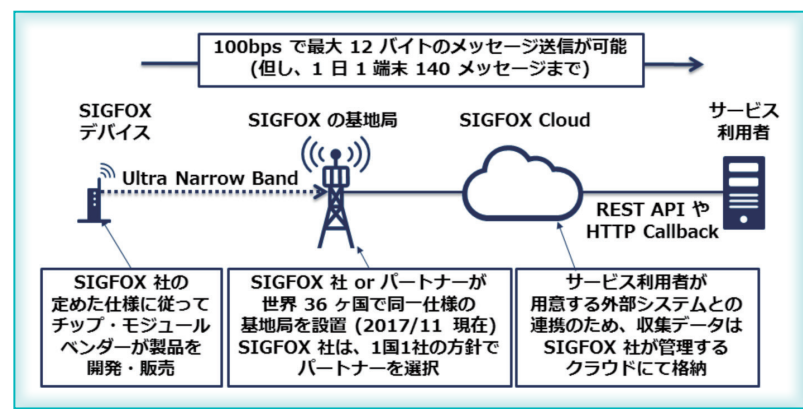

図 5 SIGFOX 通信サービス

を軽減できる，LoRaでは，どの程度信号を拡散さ せ，雑音耐性を高めるかを，拡散率（Spreading Factor）というパラメータにて調整できる。拡散率 を上げることで，より雑音耐性が高くなり，伝送距 離が伸びるが，その分伝送速度は低くなる。

LoRaの上で動作する MAC 層プロトコル LoRaWAN の仕様が，LoRa Alliance ${ }^{(6)}$ により策定 されている（図 4)。LoRaWANでは，基地局実装 の簡素化のために，MAC 層は基地局では終端せず, ネットワークサーバで終端する。ある端末からの信 号は, 複数の基地局での受信を可能とすることで, 受信性能を上げている。 LoRaWAN 仕様 ${ }^{(6)}$ は公開 されており，利用者はLoRaWANを用いた独自の ネットワーク構築が可能である。

SIGFOX $^{(7)}$ は，SIGFOX 社が開発した LPWA 技 術の一種で，雑音の影響を軽減するために次のよう
な工夫がなされている。まず，920MHz 帯の単位 チャネル $200 \mathrm{kHz}$ のうち $100 \mathrm{~Hz}$ という超狭帯域 (Ultra Narrow Band) を使いスペクトル密度を上 げている（図 3 ）。また，端末が周波数を変えて一 つのデー夕を複数回送信し，それを複数基地局が受 信できる仕様となっている。これらの工夫により， 雑音の影響を軽減し，より長距離なデー夕伝送を実 現している。また，超狭帯域の使用により。多数の 端末が存在する環境下でも，端末間の干渉が発生し にくくなっている.

SIGFOX 社及びそのパートナーは，SIGFOX 方式 を使った IoT 向け公衆通信サービスを提供してい る (図 5 )。この通信サービスでは，より多くの端末 を収容可能とするために，一端末当り 1 日に送れる メッセージ数を，最大 140 メッセージ（メッセージ サイズは最大 12Byte）までに限定している.

\subsection{IoT 向けの LTE 技術 Cat.M1,Cat.NB1}

Cat.M1 (eMTC) , Cat.NBl (NB-IoT) とは, 標準化団体 3GPP が規定する LTE 仕様における IoT 向けの端末カテゴリーである. Cat.M1, Cat. $\mathrm{NB1}$ では, チップコスト削減や収容端末数向上の ために，使用アンテナ数を 1 とし，更に送受信無 線帯域を従来の $1.4 \sim 20 \mathrm{MHz}$ からそれぞれ $1.08 \mathrm{MHz}$ (Cat.M1)，180kHz (Cat.NB1) にま で狭带域化している ${ }^{(8)}$. また, PSM (Power

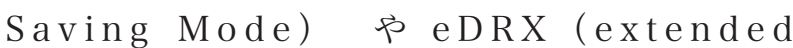
Discontinuous Reception) といった機構により, 省電力化が図られている ${ }^{(9)}$.

LTE における端末・基地局間の関係には，接続 状態とアイドル状態がある。端末は，アイドル状態 時には自身への着信を確認するために，一定時間ご とに基地局からの信号を受信する。 eDRXでは，こ の受信待ち間隔を, 従来最大 2.56 秒から, 目的に 応じて最大 44 分 (Cat.M1) 若しくは 2.9 時間 (Cat.NB1) にまで拡大する。受信していない間, 無線機能を停止させ，電力消費を抑える．着信が不 要なケースでは，より省電力を実現する PSM が利 用できる。PSM は，接続状態・アイドル状態に加 え, 新たに定義された省電力状態のときに端末をス リープさせる。このことにより，着信はできない が，その分消費電力を大幅に削減できる。必要時, 端末からの送信を可能とするために，省電力状態に おいてもコアネットワークとの接続状態は維持され ている。通常 54 分周期 ${ }^{(10)}$ で行う位置登録の夕イ

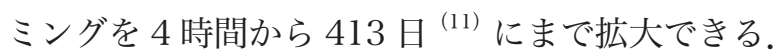


低遅延応答・通信量削減を実現する エッジコンピューティング

端末が取得した情報をクラウドに上げ，クラウド 上のアプリケーションが何らかの判断を行い，その 結果を端末に返すケースを考える。例えば，ある自 動車が自身の現在位置情報をクラウドに上げ，自身 に近付く自動車の情報を取得することで, 見通しの 悪い交差点などでの衝突事故を回避するケースが挙 げられる。このケースでは, クラウドを経由しての 位置情報交換では，衝突回避に間に合わない可能性 が高い.より遅延が少なく位置情報交換ができるよ う，より端末に近い場所にて処理を行い，素早く応 答を返すエッジコンピューティングの利用が期待さ 机ている(図6).

本章では，まず 3.1 にて LTE 網にて利用するモ バイルエッジコンピューティング (Mobile Edge Computing, MEC), 3.2 にて MEC とモバイル網 を連携するための機能である SCEF (Service Capability Exposure Function) 及び SCEF と連 携動作するモバイル網の通信スケジューリング制御 技術を紹介する．エッジコンピューティングは，低

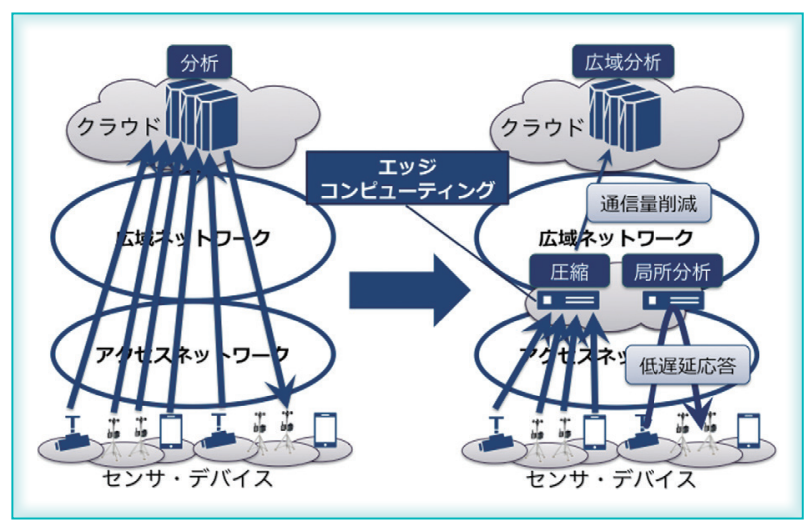

図 6 エッジコンピューティング

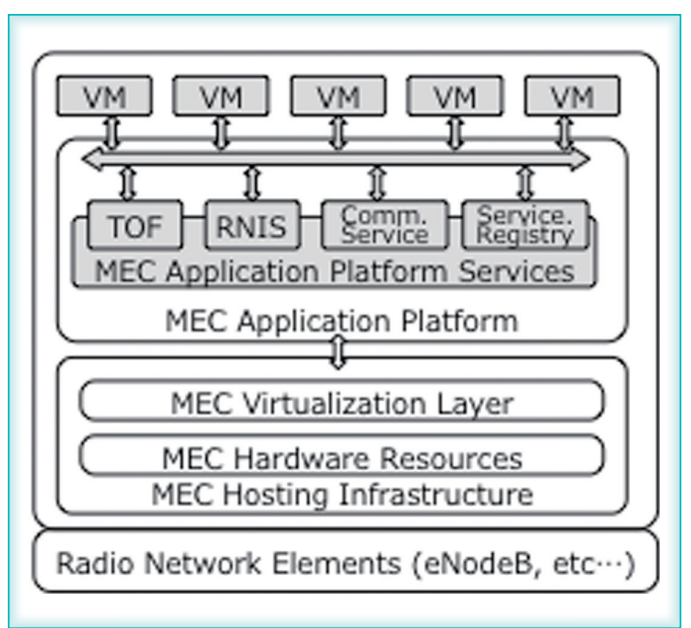

図 7 MEC アーキテクチャ (ETSI)
遅延応答のほかに通信量削減を実現するためにも活 用されている (図 6 )。 3.3 にて，エッジ処理によ り，送信デー夕量を削減する技術を紹介する。

\section{1 モバイルエッジコンピューティング}

モバイルエッジコンピューティング (Mobile Edge Computing, MEC) とは, LTE 基地局 eNodeB の近 傍に配置されたサーバにより端末から送られたデー 夕を処理することで，低遅延な応答を実現する技術 であり, 欧州の標準化団体である ETSI（European Telecommunications Standards Institute) にて 標準化が進められている*.MECの利用により，低 遅延な応答を必要とするサービスの実現が期待され ている。例えば，先に述べた自動車の衝突事故を防 ぐケースでは, 路車間・車車間の通信遅延を数十 $\mathrm{ms}$ 未満に抑える必要があるが, クラウド上で処理 する場合クラウドまでのデー夕送信に時間がかかっ てしまう (13). しかし, MEC を使い, 基地局近傍 のサーバでの処理により, 車車間通信の遅延を数十 $\mathrm{ms}$ 未満に抑えることができる.

図 7 にETSI で議論されている MECアーキテク チャを示す. MEC Hosting Infrastructureは，い わゆるサーバ仮想化を実現する仮想化基盤である。 前述の自動車における位置情報を交換するといった MEC 利用者が開発するアプリケーションは，この 仮想化基盤が提供する仮想マシン $(\mathrm{VM})$ 上で動作 する。また，MEC上でのアプリケーション動作を 支援するために, 以下に示す幾つかのサービスが, MEC Application Platform Service として提供さ れている.

・ Traffic Offload Function (TOF) は, MEC 上 で動作するアプリケーションにトラヒックを誘 導するためのサービスである. 端末の IP アド レスやアプリケーションで処理したトラヒック を再度モバイル網へと戻すパススルーモード と, アプリケーションが終端するエンドポイン トモードの二つの動作モードが用意されてい る.

- Radio Network Information Services (RNIS) は，アプリケーションが利用するための無線や ネットワークに関する情報を提供する。例え ば，端末がつながっている基地局の ID（Cell ID）や無線区間の負荷・スループットなどの 情報が提供される。

* ETSIは, MECの適用範囲をセルラ網以外にも拡大するた めに, 2017 年3月にMEC がMobile Edge Computing か $ら$ Multi-access Edge Computing の略称へと変更した ${ }^{(12)}$. 
・Communication Services は，アプリケーショ ンがサービスや他のアプリケーションと通信す るために pub/subによるメッセージング機能 を提供する。

・ Service Registry は, MEC サーバ上で動作す るサービスの稼働状態を提供する。

\subsection{SCEF}

標準化団体である 3GPP では，MECがモバイル 網と連携するためにSCEF (Service Capability Exposure Function) と呼ばれる機能が規定されて いる（図 8). SCEF は, 3rdパーティのアプリケー ションプロバイダがモバイル網上の幾つかの機能を 利用するために RESTful API を提供する。例えば, この API で QoS 設定をすることにより，指定の端 末とアプリケーションの通信を他より優先するとい う使い方ができる。

SCEF の活用例として, Communication Pattern parameters provisioning procedure と呼ばれる ケースが，3GPP が発行する文書 ${ }^{(14)}$ にて紹介され ている。このケースでは，サービス側が，デバイス の通信パターン情報を SCEF に登録することで，そ の情報が HSS（加入者サーバ）の UE Context 情報 として登録される。このことにより, デバイスの通 信パターンごとに異なるネットワークの処理を適用 することが可能となる.

SCEF と連携することで，無線区間の負荷集中を 抑えつつ, IoT 端末ごとの許容遅延時間を守るため のモバイルネットワークによる無線スケジューリン グ技術 ${ }^{(15),(16)}$ が提案されている。周期的な通信を 行う IoT 端末の増加によって, 特定のタイミング
に通信が集中し，無線区間に負荷が発生する可能性 がある。本技術では，モバイルネットワークが， サービス側から SCEFを通して受け取った IoT 端 末の許容遅延時間，単位時間当りの通信量及び無線 区間の負荷状況に応じて，端末に対して利用可能な タイムスロットを割り当てる。これらにより, 各端 末の許容遅延時間を守りつつ, 無線負荷の平滑化を 実現する。

\section{3 エッジ処理による送信データ量削減技術}

2. にて紹介した LPWA は低ビットレートである ため，限られたアプリケーションでしか利用できな い. エッジコンピューティングにて，データ圧縮や 簡単な分析を行い，送信デー夕量を削減すること で，より幅広いアプリケーションでの利用が可能と なる。

Kartakis $^{(17)}$ らは，地下にある水道管に設置され た振動センサのデー夕を分析することで漏水・破裂 箇所を特定するケースにおいて，狭帯域な LPWA ネットワークを利用可能とするために，送信データ 量を削減する方式を提案している。漏水・破裂箇所 の特定には，振動センサが $10 \mathrm{kHz}$ から $15 \mathrm{kHz}$ と いったサンプリングレートで生成する時系列データ が必要になるが, これらのデー夕を狭帯域な LPWA で送るのは困難である。そこで, 提案方式 では，センサに付随するプロセッサにて，時系列 データを軽量圧縮アルゴリズム $\left(\operatorname{miniLZO}{ }^{(18)}\right)$ に て圧縮する。通常時と異常時では圧縮率が異なるた め, 圧縮データの圧縮率を見ることで, 異常発生の 有無を判定できる。 また, Kartakis らは, 水道管 の複数箇所の振動センサにおいて, 異常を検出した

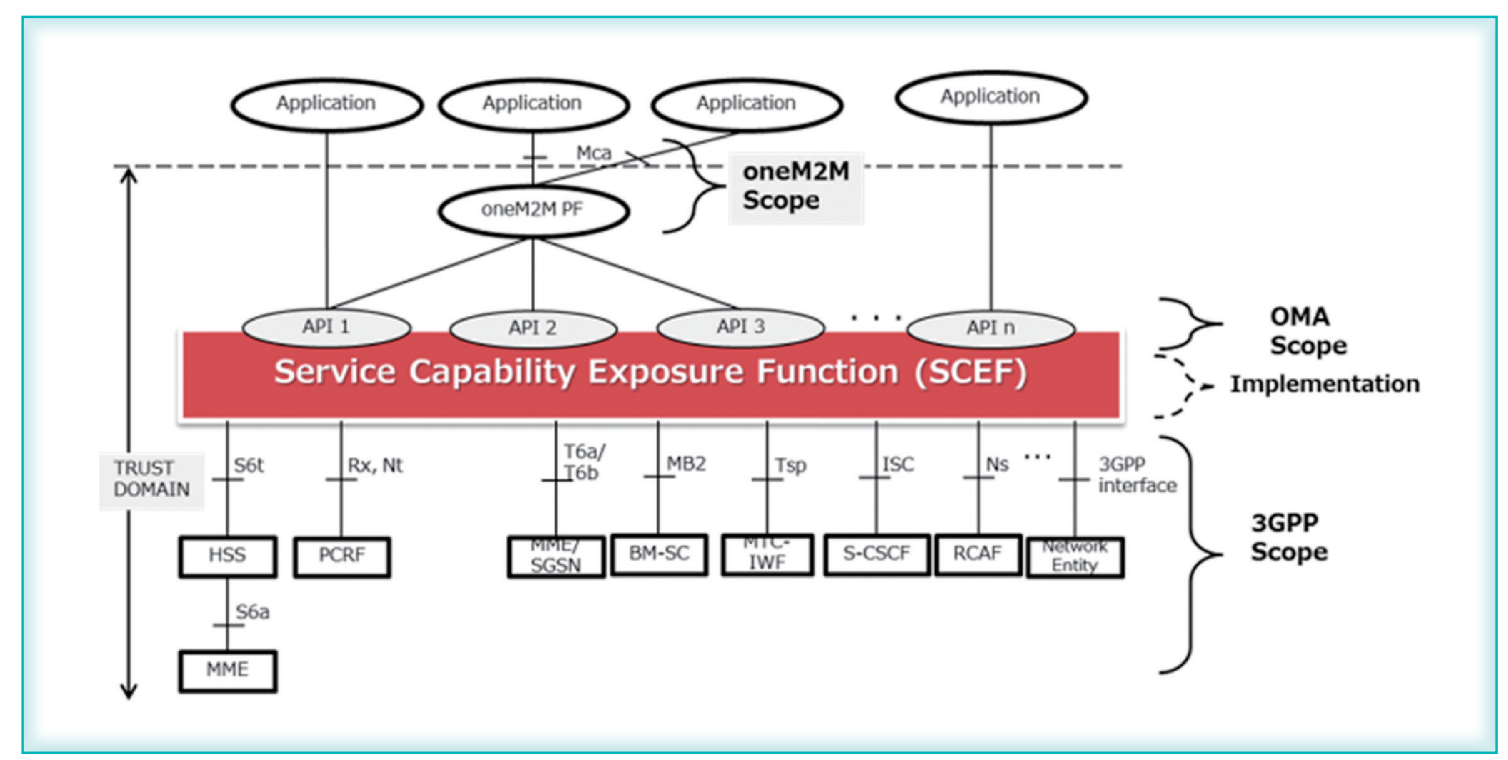

図 8 Service Capability Exposure Function 
時刻のタイムスタンプを比較することで漏水個所を 推定するアルゴリズムを開発した。提案方式では異 常検知時にタイムスタンプのみを送信すればよいた め, 従来の時系列デー夕をそのまま送信する方式と 比較し, 送信すべきデー夕量を 99\% 削減すること ができ，狭帯域な LPWA の利用を可能とした。

黒崎ら ${ }^{(19)}$ は, ライフログ向けの動画像解析をク ラウド・エッジ間にて分散処理することで, クラウ ド・エッジ間のネットワークが狭帯域であるときの 性能向上を実現している。動画像解析は, 特徵量抽 出と画像分類の二つの処理から構成される。 クラウ ド上で全て処理する場合, 狭帯域ネットワークでは 動画像をクラウドに送るのに時間がかかる。提案手 法では, エッジにて特徵量抽出を行い, クラウドに は特徵量だけを送ることで, 送信デー夕量を削減す る。これにより, 狭帯域ネットワーク使用時におい て, 単位時間にシステムが処理する動画像の量の増 加を実現している.

\section{大量のloT 情報を利活用したサービス} を実現するためのプラットホーム

クラウドに集められたデータを, 複数のアプリ ケーションにて活用するケースがある。例えば，交 通網の混雑状況は, 行政機関による今後の都市計画 の参考にされる一方，ドライバのルート選択にも利 用される。 また，一つのアプリケーションが複数の センサ情報を利用するケースも考えられる。例え ば, 農業での収穫量向上のための分析には, 温度, 湿度, 日照から土㗒の成分まで様々なセンサ情報を 活用する.

このようなケースに対応するために，クラウド上 には次の機能を備えるプラットホームの構築が求め られる。

(1)複数のアプリケーションを動作・連携させる機 能

(2)複数のアプリケーションへ適切なコンテキス 卜情報を流通させる機能

(1)はクラウドの代表的サービスである IaaS が提 供する機能である。例えば, 複数のアプリケーショ ンが同一の分析をする場合，それぞれが別々に分析 するのではなく，あるアプリケーションが分析のみ を行い, 分析結果を必要とするアプリケーション間 で共有する方が効率が良い。このように複数のアプ リケーションが動作するだけではなく，それらが連 携できる必要がある。(2), IoT 端末から送られて きたデー夕をそのまま流通させるのではなく, コン
テキスト情報に変換し流通させる。例えば，様々な 種類の温度センサは，それぞれ独自の符号化を施し て温度の測定值を出力するため, (2)ではこれらを統 一した形式に変換してアプリケーションに渡す役割 が求められる。また, 温度センサ以外にも, 湿度セ ンサや日照センサなど異なるセンサを扱うために は，測定值がどの種別の情報なのかも合わせてアプ リケーションに通知する必要がある。そのため, (2) は, IoT 端末から送られてきた情報を, 属性（例： 温度）と属性值（例: $26.5{ }^{\circ} \mathrm{C}$ ) の組み合わせから 成るコンテキスト情報に変換し，その情報を必要と するアプリケーションへと渡す。

(1)に加え，(2)を備えたプラットホームをここでは IoT プラットホームと呼ぶこととする。本章では, オープンに利用可能なIoT プラットホームである FIWARE 4.1 で解説し, その後 4.2 にて, コン テキスト情報に意味的情報（セマンティクス）を付 与することで, アプリケーションの再利用性を向上 させる取組について説明する.

\subsection{FIWARE}

FIWARE $^{(20)}$ は，欧州の官民連携プロジェクト FI-PPP で開発された IoT プラットホームの一つで ある. FIWARE は, スマートシティや農業など八 つの領域での活用を目的として開発された，コンテ キスト情報流通のためのサービス基盤であり, 様々 なケースにて活用できる共通モジュール群 (Generic Enablers, GEs) と領域に特化したモ ジュール群 (Domain Specific Enablers, DSEs) から構成される。

また, 誰もが利用可能なオープンな仕様を目指し ている点が特徵である。モジュール間のインタ フェースには, オープン仕様なインタフェースであ る NGSI (Next Generation Service Interface) が 採用されている。これらのインタフェースを持つ多 くの機能モジュールがリファレンス実装 (Generic Enabler reference implementations, GEris) とし てオープンソース (OSS) で多数公開されている. また，このインタフェースを使うことで，モジュー 儿間接続は疎結合となるため，3rd パーティの実装 を組み合わせて使用することも容易となっている. 3rdパーティも含むこれらのモジュール群は, FIWARE Catalogue ${ }^{(25)}$ と呼ばれるWeb サイトに て分類され, 紹介されている。これらの中から必要 なモジュールのみを組み合わせて利用することで, 独自の IoT プラットホームを構築することができ る。 
NGSI とは, 元々通信事業者網の機能をサービス 事業者によって操作するために定められたインタ フェース仕様であり，標準化団体 OMA（Open Mobile Alliance) にて標準化された。NGSI では, 呼制御，課金や携帯端末の位置情報・プレゼンス情 報取得といった多くの API が定義されている. FIWAREでは, このうちコンテキスト情報に関連 する NGSI-9 Context Entity Discovery Interface と NGSI-10 Context Information Interface ${ }^{(21)}$ を, FIWARE 向けに拡張した仕様を採用している.

FIWARE には，4.の冒頭で述べた IoT プラット ホームが持つべき機能 (1), (2)を提供する共通モ ジュールのリファレンス実装 GEris が用意されてい る. (1)に関しては, メジャーなクラウド基盤ソフト ウェアである OpenStack ${ }^{(26)}$ や docker ${ }^{(27)}$ が用意 されている，他の GEris はこれらの基盤上で動作可 能なよう整備されている。また，(2)関しては， FIWAREにおけるコンテキスト情報流通の中心を 担う Context Broker が Generic Enabler として用 意されており，リファレンス実装 GEris として ORION Context Broker（以後 ORION と表記）が 公開されている。 ORION は Publish/Subscribe モ デルに基づき情報流通を担うモジュールである。ア プリケーションは ORION に対してコンテキスト情 報の属性を含む購読 (Subscribe) メッセージを送 ると, ORION はコンテンツ情報の属性值が更新さ れたときに，そのコンテキスト情報を購読している アプリケーションに対して更新されたコンテンツ情 報を発行 (Publish) する.

図 9 に FIWARE のモジュール群を組み合わせて 構成した IoT プラットホームの一例を示す。以下, 各 GEs の動作を説明する (IoT Broker, IoT Knowledge Server は4.2にて説明する)。

・IoT Agents : IoT デバイスからのデー夕転送

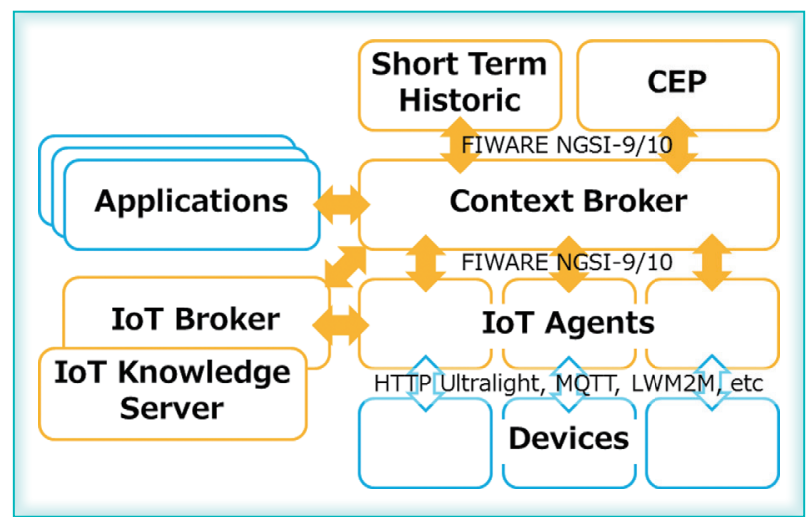

図 9 FIWARE により構成された IOT プラットホームの 一例
のために, HTTP Ultralight, MQTT や OMA Lightweight M2M (LWM2M) といった様々 なプロトコルが使用されている. FIWAREで は, これらのプロトコルに対応した IoT Agent が，受け取った情報を NGSI 規定のデータモデ ルに変換し, Context Brokerへと渡す。

· Context Broker : IoT Agentsにより変換され た情報を必要とする各モジュールへと通知す る.

- Short Term Historic : 最大値 / 最小值, 平均 / 分散といった值を計算するために, 時系列デー 夕を保持する。保持されたデー夕は, 要求に応 じて, 必要とするモジュールへ Context Broker 経由で提供される.

• CEP (Complex Event Processing)：ある一定 時間内に生成された複数のイベントを分析し, それらをまとめた新たなイベントを, 必要とす るモジュールに Context Broker 経由で通知す るといった動作を行う。または, CEP モジュー ルが分析後即座に必要な対応 (例 : 管理者に メール通知）を取ることも可能である.

\section{2 アプリケーションの再利用性向上のためのセマ ンティック情報活用}

スマートシティなどの IoT アプリケーションの 再利用を向上させるためには，センサなどから得ら れるデー夕の意味を考慮する必要がある。例えば, 同じ種類のセンサから得られるデータであっても, 使われ方によって意味が異なる場合があるからであ る。例えば，異なる都市間で同じ温度データが利用 されていたとしても，その温度が，“ある時刻にお ける”温度を指すのか，あるいは，“ある一定期間 の平均の”温度を指すのかによって意味は異なる。 その結果，アプリケーションは，同じ “温度”とい う名前のデータであっても, その意味の違いによっ て処理を変更する必要がある。

4.1 で述べた FIWAREも，同様な問題を持って いる. FIWARE のアプリケーションは NGSI-9/10 で規定された API を使って, コンテキストデータ （属性と属性值）にアクセスする。そのため，アプ リケーションとデバイス間が疎結合になり，アプリ ケーションの再利用性が向上している。例えば, データが “温度”というコンテキストで管理されて いれば，そのデータの生成源が，固定センサや巡回 バス，また，人が持つスマートフォンのように異 なっていたとしても, 同じロジックでこの情報を报 うことができる。しかし，先に述べたようにコンテ 
キストデータによる抽象化だけでは意味の違いには 対応できていない.

この問題に対応するために提案された IoT Broker $^{(22)}$ では, NSGIメッセージに付与されたセ マンティック情報に基づいて, クエリが要求する デー夕を推論し提供することで意味の違いを吸収す る。これにより，例えば，ある都市のセンサデータ を使うアプリケーションを別の都市にて使用する場 合でも，IoT Broker が各都市におけるデー夕の意 味の違いを吸収し, 適切なデータをアプリケーショ ンに渡すことができる。また，セマンティック情報 からデー夕の物理位置を特定することで, 例えば, 地理的な範囲を指定したクエリを，その範囲のデー 夕を持つブローカにのみ転送するといった効率化が 実現できる。セマンティックに基づいて IoT Broker が意味変換のためのルールは, IoT Knowledge Server が管理する ${ }^{(22) .}$

図9では, IoT Broker は, IoT Agents と Context Broker の間に配置され，様々な IoT Agents から通 知されたデー夕の意味の違いを吸収する役割を担う。 IoT Broker は IoT Agents からデー夕を受け取ると, IoT Knowledge Server が管理するルールに基づい てデー夕を変換し, Context Broker に渡す。

セマンティック情報を扱うという考方方は，セマ ンティックウェブ(23) と呼ばれる技術がベースと なっており, 現在この考え方の IoT プラットホー ムへの適用が注目されている。例えば，IoTFIESTA $^{(24)}$ では, この考え方に基づいたテストベッ ドを提供しており，利用者によってスマートシティ などのアプリケーションの相互接続性に関する検証 が進められている。

\section{あとがき}

本稿では，IoTを活用する上での課題を解決する ための技術を紹介した。本稿にて紹介した技術以外 にも，各種センシング技術，IoT 端末の管理技術， ネットワークコンピューティングなどの通信・処理 基盤技術，デー夕分析技術など多岐に渡る技術が存 在する。本稿では誌面の関係から重要だと思われる 技術に絞って解説したが，本稿で触れられなかった 技術は，各自参考文献 ${ }^{(28)}$ （32) などを参照してほ しい. 本稿の内容が，今後の IoT 活用の発展の一 助となれば幸いである。

謝辞 本研究の一部は, 総務省委託研究「IoT 共 通基盤技術の確立・実証」の成果です。また，情報 提供や内容確認に協力いただいた NEC の同僚であ
ろ内田曜教氏，井上高道氏，藤波誠氏に感謝しま す.

文献

（1）総務省，平成 27 年度版情報通信白書，平成 27 年.

（2）総務省，平成 29 年度版情報通信白書，平成 29 年。

(3) L. Vangelista, A. Zanella, and M. Zorzi : "Longrange IoT technologies: The dawn of LoRa (TM) ," Future Access Enablers of Ubiquitous and Intelligent Infrastructures, pp. 51-58. Springer, 2015.

(4) F. Sforza, “Communications system," US Patent 8406275, 2013.

(5) A. J. Berni and W. D. Gregg, "On the utility of chirp modulation for digital signaling," IEEE Trans. Commun. vol. 21, no. 6, pp. 748-751, 1973.

(6) “LoRa Alliance,” https://www.lora- alliance.org/.

(7) “SIGFOX,” https://www.sigfox.com/.

（8）中村武宏, 永田 聡, 梅田大將, 高橋秀明, 安藤 桂, “LTE-Advanced Release 13 標準化技術概要,” NTT DOCOMO テクニカル・ジャーナル, vol. 24, no. 2, pp.32-37, 2016.

（9）武田和晃，ウリ A. ハプサリ，高橋秀明, 藤島大輔, ミャオ シェン, “LTE Release 13 における IoTを 実現する技術, ” NTT DOCOMO テクニカル・ジャー ナル , vol. 24, no. 2, pp. 38-49, 2016.

(10) 3GPP TS 24.301, "Non-Access-Stratum (NAS) protocol for Evolved Packet System(EPS)(Release15)," 2017.

(11) GSM Association, "LTE-M Development Guide to Basic Feature set Requirements,” , https://www. gsma.com/iot/wp-content/uploads/2017/09/LTEM-Deployment-Guide-CLP.29-v1.0.pdf, 2017.

(12) European Telecommunications Standards Institute (ETSI), "ETSI multi-access edge Computing starts second phase and renews leadership team," http://www.etsi.org/newsevents/news/1 180-2017-03-news-etsi-multi-ccessedge-computing-starts-second-phase-and-renewsleadership-team, 2017.

（13）松田尚久, 高木健樹, 堀内 翔, 青木宏樹, 芥川愛 子, “NFV で実現する IoT ネットワーク,” NEC 技 報, vol. 68, no. 3, pp. 36-41, 2015.

(14) 3GPP TS 23.682, "Architecture enhancements to facilitate communications with packet data networks and applications (Release 13),” 2015.

（15）岩井孝法, 長谷川 剛, 若宮直紀, “モバイルコア ネットワークへのアクセス負荷を平滑化するための バックオフ機構の拡張, ”信学技報, MoNA201360, pp. 67-72, 2014.

(16) G. Hasegawa, T. Iwai, and N. Wakamiya, "Temporal load balancing of machine type communications in mobile core networks," Proc. 2015 IFIP/IEEE International Symposium on Integrated Network Management (IM) , 2015.

(17) S. Kartakis, W. Yu, R. Akhavan, and J. A. McCann, "Adaptive edge analytics for distributed networked control of water systems," Proc. IEEE First International Conference on Internet-ofThings Design and Implementation (IoTDI) , pp. 72-82, 2016. 
(18) J. Kraus and V. Bubla, "Optimal methods for data storage in performance measuring and monitoring devices,” Proc. Electronic Power Engineering Conference, 2008.

（19）黑崎裕子，竹房あつ子 , 中田秀基 , 小口正人，“リア ルタイム動画像解析アプリケーションフレームワー クにおけるセンサ・クラウド間負荷分散の性能評 価,”信学技報, Vol. 115, No. 230, DE2015-24, pp. 23-28, 2015.

(20) “FIWARE," https://www.fiware.org/.

(21) “NGSI context management," http://www. openmobilealliance.org/release/NGSI/V1_020120529 - A/OMA-TS-NGSI_Context_ Management-V1_0-20120529-A.pdf, Open Mobile Alliance, 2012.

(22) F. Cirillo, M. Bauer, S. Gessler, G. Solmaz, B. Cheng, and E. Kovacs, "IoT Broker," FIWARE Summit, Malaga, 2016.

(23) "W3C semantic web activity," The World Wide Web Consortium (W3C), https://www. w3.org/2001/sw/.

(24) “IoT FIESTA," http://fiesta- iot.eu/, 2017.

(25) "FIWARE Catalogue," https://catalogue.fiware. org/.

(26) “The OpenStack project," https://www. openstack.org/.

(27) “Docker," https://www.docker.com/.

(28) A. Al-Fuqaha, M. Guizani, M. Mohammadi, M, Aledhari, and M. Ayyash, "Internet of things: A survey on enabling technologies, protocols, and applications," IEEE Commun. Surveys \& Tutorials, vol.17, no. 4, pp.2347-2376.

(29) P. P. Ray, "A survey on Internet of things architectures,” Journal of King Saud UniversityComputer and Information Sciences, 2016.

（30）田中裕之，高橋紀之，川村龍太郎，“IoT 時代を拓く エッジコンピューティングの研究開発,”NTT 技術 ジャーナル , vol. 27, no. 8, pp. 59-63, 2015.

(31) D. Sabella, A. Vaillant, P. Kuure, U. Rauschenbach, and F. Giust, "Mobile-edge computing architecture: The role of MEC in the

Internet of things," IEEE Consumer Electronics Mag., Vol. 5, No. 4, pp. 84-91, 2016.

(32）飯田勝吉，“エッジコンピューティング研究開発の現 状と今後の課題, ”信学技報, vol. 117, no. 187, IA2017-16, pp. 25-30, 2017.

(平成 29 年 11 月 2 日受付, 平成 30 年 1 月 19 日再受付)

鈴木一哉（正員）

1997 都立大大学院工学研究科修士課 程了. 同年 NEC 入社. ネットワーク 機器開発，経路制御・SDN の研究開 発に従事. 2011 筑波大大学院ビジネ 不科学研究科博士後期課程了. 2014. 2018 電通大大学院情報システム工学 研究科客員准教授. 現在, 秋田県立大. システム科学技術・准教授. 博士 (シ ステムズ・マネジメント).

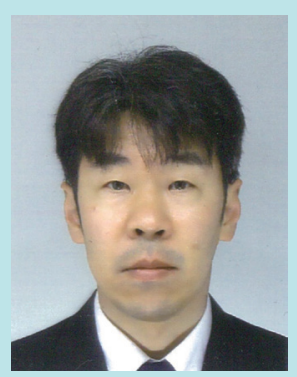

\section{森本昌治 (正員)}

2004 神戸大·エ・卒. 2006 同大学 院自然科学研究科（情報知能工学専 攻）博士前期課程了. 同年 NEC 入 社. 2015 プリンストン大客員研究 員. 2016 NEC 北米支社を経て, 現在 NEC システムプラットフォーム研究所 主任研究員. SDN/NFV ば゙ネットワー ク制御の研究開発・製品開発に従事。

\section{岩井籽法 (正員)}

2002 信州大.工卒. 2004 同大学 院工学研究科博士前期課程了. 同年 NEC 入社. 現在, NEC システムプラッ トフォーム研究所主任研究員. 慶大大 学院理工学研究科総合デザイン工学 後期博士課程に在学中. IoT 通信ネッ トワークの設計・制御技術の研究に従 事. 2016 第 64 回電気科学技術奨励 会会長賞並びに電気科学技術奨励賞, 2017 IEEE CQR Best Paper Award 各受賞. 